医機学 Vol.85, No. 5 (2015) （13 )

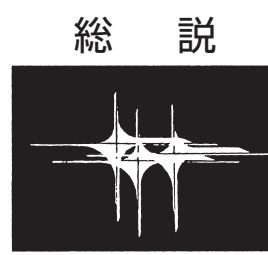

\title{
(一般財団法人 日本医科器械資料保存協会「医科器械史研究賞]受賞論文)
}

\section{十二指腸鏡と治療内視鏡機器の開発ならびにその世界展開}

\section{1.はじめに}

現代における消化器内視鏡の発展は 1950 年 の宇治 ${ }^{1)}$ による胃カメラ（オリンパス）の開発 に始まるといってよかろう。それまでは，一部 の先駆者以外には胃内を観察あるいは撮影する ことはできなかった，軟性胃鏡の時代は専ら胃 内の写生をペインターがおこない, それに基ず いて図譜が作成されていた。胃カメラは盲目撮 影法であったとはいえ, 胃内の鮮明な写真撮影 に成功した。 そのおかげで早期胃癌診断学がわ が国において成功をおさめたのである，次い で 1958 年には Hirschowitz ${ }^{2)}$ が胃ファイバー スコープの開発に成功し, 直視下観察で診断が 可能になった. しかし, 胃内写真撮影は長らく 胃カメラを併用しておこなわれていた。ファイ バースコープの虚像をカメラ撮影はできないで あろうというのが当時の常識であった。長らく カメラのアタッチメントもなく, 専用のカメラ もない時期があったのである。 まして膵臓, 胆 道疾患に関しては内視鏡的アプローチ法がな く, 膵臓に関しては低緊張性十二指腸造影によ る間接所見と PS テスト (パンクレオザイミン・ セクレチン・テスト), それに随伴する膵液細 胞診を参考にするほかなかった. 当時, 胆道に 関してはビリグラフィンによる経静脈的胆囊胆 道造影法が用いられていた。 胆囊造影法として は，あらかじめ経口的にテレパークを服用させ て胆霊造影をおこない, 卵黄 2 個を収縮剤と

* 昭和大学名誉教授
藤 田 力 也 ${ }^{*}$

して服用させ, 頭部下位の体位で下部胆管の造 影に偶々成功することができる程度であった。 十二指腸ファイバースコープの完成を俟って脺 胆道疾患のアプローチが可能となり, その後の 診断法, 内視鏡治療へと発展していった。 その 歴史について述べる。

\section{2. 十二指腸ファイバースコープの開発}

十二指腸ファイバースコープの開発に先 立って胃カメラと似たタイプの十二指腸カメラ の開発もおこなわれていたが, 球部までの写真 に止まりファーター乳頭部の観察には至らな かった ${ }^{3)}$. スコープそのもの構造, 挿入法にも 問題があった.

1968 年, McCune (USA) は Eder 型ファイ バースコープを用いてファーター乳頭から膵管 の造影に成功し発表した ${ }^{4)}$. スコープの仕様詳 細については記載がないが，直視，側視の切り 替え式で先端部分にはファーター乳頭部観察の ため, 乳頭部粘膜から距離をとるバルーンを装 着していた，十二指腸への挿入に $50 \%$ の成功 率, カニュレーションにその半数, したがって 全体の成功率は $25 \%$ に過ぎなかった，スコー プの改良と使用者の熟練が必要であると記載さ れているが, このスコープの開発はその後の報 告がない，普及することもなかった。 そのた め, 本邦の大井は十二指腸ファイバースコープ （FDS）の開発を町田製作所と共におこなって 1969 年ついに膵管造影に成功した ${ }^{5}$. 同時期 に高木は町田ファイバースコープFDSを用い て，全身麻酔術下に膵管胆管造影に成功してい 
(14) 医機学 Vol.85, No. 5 (2015)

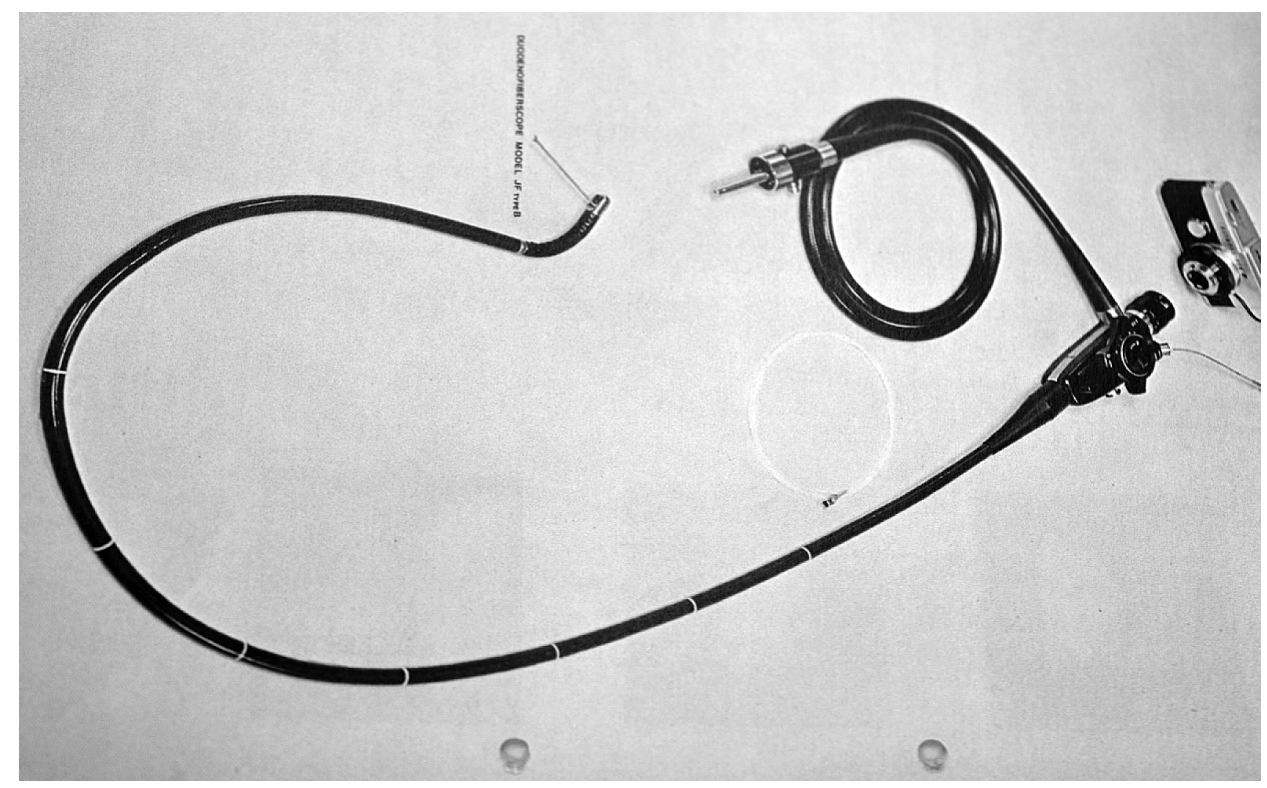

図表 $\quad 1$ JF-B 全景

\begin{tabular}{|l|c|c|c|c|c|c|}
\hline & 視野角 & 先端金属長 & スコープ長 & アングル & 鉗子孔 & 照明 \\
\hline $\begin{array}{l}\text { JFB } \\
\text { (オリンパス 1970) }\end{array}$ & 側視 70 & $20 \mathrm{~mm}$ & $1250 \mathrm{~mm}$ & $\begin{array}{c}\text { u,d. } 120 \\
\text { r,l. } 90\end{array}$ & 右側 & light-guide \\
\hline $\begin{array}{l}\text { FDSL } \\
\text { (町田 1970) }\end{array}$ & 側視 52 & $28.5 \mathrm{~mm}$ & $1465 \mathrm{~mm}$ & $\begin{array}{c}\mathrm{u} 120 \mathrm{~d} .90 \\
\text { panning syst. }\end{array}$ & 右側 & light-guide \\
\hline \begin{tabular}{l} 
(当時の胃ファイバースコープ) \\
\hline $\begin{array}{l}\text { GFB } \\
\text { (オリンパス 1966) }\end{array}$
\end{tabular}$\quad$ 側視 55 & $55 \mathrm{~mm}$ & $850 \mathrm{~mm}$ & $\begin{array}{c}\text { u.d.90 } \\
\text { r. l. (-) }\end{array}$ & 左側 & 電球 \\
\hline
\end{tabular}

図表 2 JF-B 仕様書

る ${ }^{6)}$. 同年の放射線学会関東地方会で大井は膵 管造影成功例を報告し, その地方会で高木は追 加発言をおこない膵総胆管造影の成功例を報告 した。

同時期にオリンパスグループでは小委員会 を立ち上げ，筆者らの東大分院グループ ${ }^{7)}$, 東 京医大グループ ${ }^{8)}$, 県立がんセンター新潟病院 グループ 9) がそれぞれに独立してスコープを完 成させ日本内視鏡学会誌に同時に原著論文と して報告した，オリンパスから JF- B , 次い でJF-B2 として市販された。 直視式の JFD も 検討されたがカニュレーションはできないため に市販はされなかった。 十二指腸ファイバース コープの全景と仕様については図表 1,2 に示 した。

筆者らは主として JFB の十二指腸下行脚へ の挿入法の確立に努めた ${ }^{10)}$. 胃ファイバース
コープとは全く異なるスコープの作成が求めら れた. 問題点はファーター乳頭部の観察に 100 パーセント成功することであった．まず十二指 腸球部までは挿入できても下行脚への挿入は 1 -2 時間かけてもできず, 共同研究者の相馬は 各症例の挿入に挑んだ．鉢巻きスタイルでタオ ルを首に巻き汗みどろの格闘であった，当時の レントゲン透視室にはエアコンはなく, テレビ モニタもなかった。この段階で学んだことは, スコープは胃スコープより長いこと, 先端硬性 部はなるべく短いこと, 操作部のひねりに従っ てスコープの追従性が良いことが必須であっ た。

挿入法の完成は図 3 に示す通りであった ${ }^{10)}$. (図表 3 ) 進藤ら ${ }^{8)}$, 小越ら ${ }^{9)} も$ 同様に苦闘を 重ねてスコープの完成にこぎつけている.

ファーター乳頭を正面視するには上下・左 


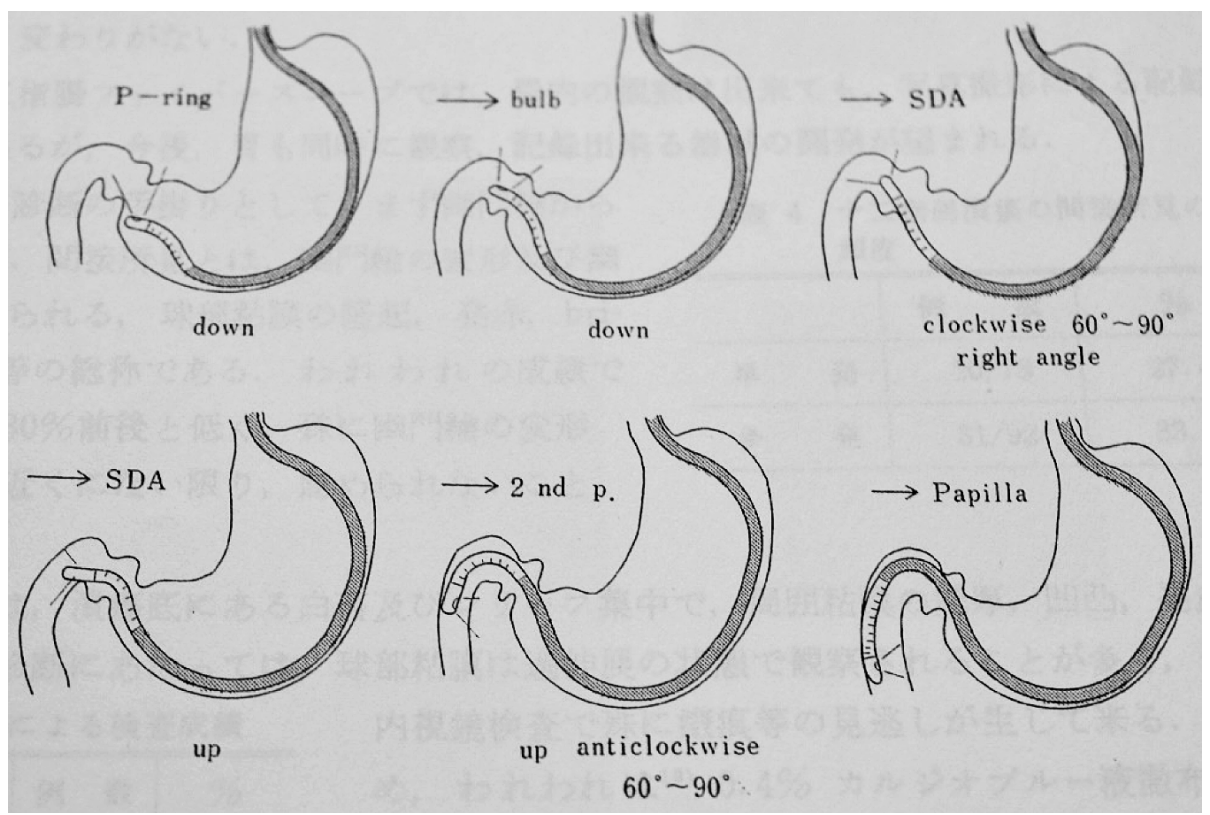

図表３挿入法（文献 10）

右のアングルで制御が可能であった。 町田製ス コープは追従性に欠けたようで，パンニングシ ステムが補助的に採用されたようである。当時 オリンパスでは大腸ファイバースコープの開発 もおこなわれており，スコープシャフトの製作 にあたっては追従性を重視していたので，十二 指腸スコープのシャフトは追従性の良いものに 仕上がった. 挿入法はプッシュ法であったが, カニュレーションも満足できる程度に完成し た. 念願の膵癌診断のための研究も世界中で開 始された。

1970 年のヨーロッパにおける世界消化器病学 会では十二指腸ファイバースコープの完成につ いてわが国から発表されると海外からの見学者 が急増した. 東大分院で城所, 相馬とともに応 対した記憶がある. 1972 年の国際消化器病学会 （Paris）で筆者は EPCG として発表をおこなっ た.ファイバースコープを用いて膵管胆管造影 をおこなう検査法は日本では EPCG (endoscopic pancreato-cholangio-graphy）と呼ばれていた が, 1974 年の世界消化器病学会 (Mexico) のシ ンポジウムで, ERCP (endoscopic retrograde cholangio-pancreatography) と命名され世界統 一された ${ }^{11)}$.

\section{3. 内視鏡治療への発展亡機器の開発}

1972 年にパリの学会後に, 当時西ドイツの Erlangen 大学でワークショップが開催された が, その折に一部でファーター乳頭の内視鏡治 療が話題になった，相馬と筆者は東大分院で犬 を用いた実験を終了し，相馬の赴任先杏林大学 においてプッシュ型ナイフを用いて 4 例中 3 例 にパピロトミーが成功した ${ }^{12}$. Classen は嵌頓し た総胆管結石を生検鉗子で除去し成功したのが きっかけでプル型ナイフを用いてパピロトミー に成功した ${ }^{13)}$. 川井らは矢じり式の電気コテを 用いて総胆管結石の治療に成功している ${ }^{14)}{ }^{15)}$.

われわれはワイヤが一方向に飛び出す push 型 knife（相馬ナイフ）を製作してファーター 乳頭部切開に成功した。このナイフの完成まで にはストーリーがあった。切開・止血・縫合は 外科手術の原則とされ, 一方向の切開は収縮を きたすのでおこなわないとされた，当時，小野 らの外科手術ではファーター乳頭形成術という 繊細な手術が㧍こなわれていて, 十二指腸乳頭 部を露出させたうえで, 乳頭部を切開して総胆 管遺残結石を摘出し, 乳頭部を丁寧に縫合, 止 血する方法であった ${ }^{16)}$. したがって手技が簡 
単で切開のみで終了する内視鏡的なパピロト ミーに関しては外科サイドから反対論が強かっ た，止血，縫合をおこなわずに治療終了とした からである. 一方向の切開は外科的な原則に合 致しないので, パピロトミーナイフには 3 方 向ナイフを初期に考案したが, 先端部が硬くて 乳頭部へ挿入が困難であり，3本のナイフワイ ヤでは出力が分散し乳頭部組織の損傷が大きく 断念した. 先に述べた通り一方向ナイフへ転換 して, 成功した ${ }^{12)}$.このナイフの成功は川井 ら, Classen らにも伝わり, それぞれのナイフ が考案され臨床化されたという事情があった。 Classen らは pull 型ナイフを考案し, 川井らは push, pull 型両用ナイフを報告している. 切開 用ナイフに関しては次々に新しいデバイスが報 告され, 報告者やメーカによっても各自に製作・ 市販されたのでその種類は多い.

電気メスに関しては内視鏡専用の機種開発 が望まれたが, 当初には存在せず, 外科手術用 を準用するほかなかった。オリンパスは PSD を開発したが, 当初は真空管方式の大型の器械 であった，凝固波を用いるか，切開波か，ある いは混合波かについても議論がながく続いたの である. 相馬らは火花放電で初めて切開ができ ること, それまでには初期加熱が必要なこと, 出力が小さいと切開までに時間がかかり組織破 壊が大きいことなどを実験して報告した ${ }^{17)}$ 。ま た, 総胆管結石の除去法に関しても苦労した. 当時, バスケットワイヤで切開当日に除去する ことは術後出血防止のために禁じられ，自然排 石を待って便漉しを扔こなっていた，結石の嵌 頓によってしばしば閉塞性胆管炎を経験した が, バスケットカテーテルや胆道ドレナージが できるようになり解決した ${ }^{18 \sim 20)}$.

NB カテーテル (naso-biliary) の導入もその 解決方法として有用であった。

処置具としては, 砕石用バスケット, ドレナー ジ用ステントの開発が進むにつれてスコープの 対応は JF-1T, TJF, 親子式胆膵スコープ ${ }^{21)}$ な どへと発展した. 処置用スコープのニーズに伴 い, 鉗子孔も拡大へ改変がおこなわれている. 1993 年代における治療内視鏡への進展状況を見 ると, 次のものが含まれていた。内視鏡的乳頭
括約筋切開術から始まり, 膵胆管ドレナージ術, ステント挿入術, 総胆管結石の砕石術（機械的. レーザー・電気衝撃波など）が含まれていた. 現在ではさらに EUS (超音波内視鏡), CT, MRI など画像診断法の進展に伴い, ERCP の役 割は初期の診断的目的から次第に治療目的へと 大きく変化している ${ }^{22}$.

\section{4. 世界への消化器内視鏡機器の展開}

消化器内視鏡機器の開発が主として日本で 進展してきたことはすでに述べたが，胃カメラ の原型はドイツ, アメリカにあり，ファイバー スコープの原型はアメリカの ACMI であり, 電子スコープの原型はアメリカの Welch-Allyn であった. ファイバースコープから電子スコー プへ変革しても事情は変わらず, 内視鏡機器産 業として日本勢のみ（オリンパス・フジメデイ カル・ペンタックス）が世界への機種供給源で あり続けている.

日本製内視鏡の市場性について述べる，世界 人口は約 70 億人に達するがその分布状況はお およそ次の通りである。

アジア太平洋地区 40 億人

アフリカ大陸 10 億人

ヨーロッパ中近東 10 億人

アメリカ大陸 10 億人

国際的な交流について個人的な経験を述べ る. 小生にとっては十二指腸ファイバースコー プの開発に関わったおかげで日本への見学者・ 研究者との関係ができ, 実地指導に出かけた先 で, 諸外国の内視鏡医らと接することができた. 以後，長期にわたる親交が継続できている. 受け入れ人数は東大分院から始まり, 記録に残 る人数は見学者を含め 300 余名に上り，訪問国 は国際学会・役員会を含めると 50 数か国にの ぼる，かつての研修医の子息から，最近では孫 子の研修までお世話するようになった，最近で はメールが届き, 関係者の到着日を知らせてく ることもある，日本で開発された新しい手技の 習得に研修・見学者が後を絶たない. 学会の権 威者との親交関係はあえて求めず，若い内視鏡 医との交流を中心に交流を進めてきたおかげで あろう。受け入れに伴って助力してくれる関係 
者に感謝している.

1995 年 3 月 12 日（日）昭和大学藤が丘病院 に「消化器内視鏡 - 国際研修センター」を開設 した. 消化器内視鏡国際研修センターは運営委 員会規則として昭和大学の理事会に承認され た. 開所式には中国大使館一等書記官張必成, 昭和大学理事長天野長久, 学長武重千冬, 藤が 丘病院名誉院長小林太刀夫, 日本消化器内視鏡 学会理事長崎田隆夫, 早期胃癌検診協会理事長 市川平三郎, 日本内視鏡医学研究振興財団理事 長丹羽寛文, ほか全国の大学病院関係者, マス コミ関係者, メーカ関係者など約 150 名の参加 を得ることができた，図表 4 の写真は当時の昭 和大学天野長久理事長の祝辞風景である. 開設 の目的は海外からの研修生の受け入れと研修事 業を推進し, 内視鏡に関する実験, 技術の習得 とともに共同して研究, ライブデモ・カンファ ランスを抗こなうことであった. 昭和大学の付 属施設として, 正式に承認を得ることができた. この施設は 2000 年に新しく開設された横浜市 昭和大学北部病院消化器センターへ移設され, 規定も変更され現在は工藤進英センター長が主 宰し, 継続している。

\section{5. 消化器内視鏡の研修事業（世界消 化器内視鏡機構との関連事項)}

㟝田教授, 村上教授, 白壁教授, 城所教 授, 市川国立がんセンター院長を主体とした OTCA（現 JICA）で早期胃癌診断コースが開 始されたのが 1969 年であった．小生は東京都 がん検診センター, 昭和大学藤が丘病院, 癌研 病院 (大塚・有明) と施設は変わっても, 海外 からの研修希望者は途切れることなく継続し, 海外への学会出張, 技術指導へ出かけるごとに 友人が増え, 子息, 子女の希望者とかかわりが あった。

内視鏡医学研究振興財団からの依頼, メー カからの依頼も多かった。 また, 丹羽寛文理 事長指導のもと, 世界消化器内視鏡学会機構 (OMED, 現 WEO) の役員 (faculty member, committee member, secretary general, vicepresident) を務めたこと, APSDE (Asian Pacific Society of Digestive Endoscopy) の役

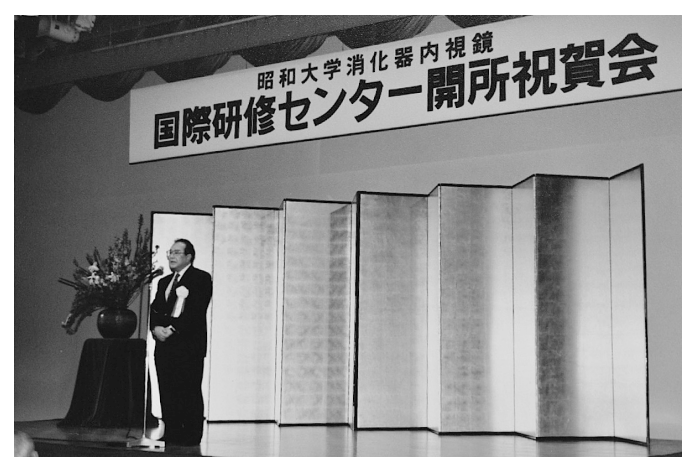

図表 4 国際研修センター開所式

員 (committee member,vice president) を務 めたこと, 日中消化器病・内視鏡研究会 (日本 側会長), 日韓消化器内視鏡研究会 (カウンセ ラー）に関係することができた. 日本消化器内 視鏡学会の国際委員会担当役員を務めたので, それに伴って海外の内視鏡医との関係はより緊 密になり, 現在も継続している ${ }^{23)}$.

\section{6. 展 望}

ものごとには順序がある．完全を目指しても 初めから完成させることは困難である. 十二指 腸ファイバースコープの挿入法にも順序があっ た. push 法が完成されて, 初めて pull 法がべ ターな方式として導入された。 パピロトミーナ イフにしてもそうであった. push タイプがあっ て, その欠点を補って pull 法が普及型となっ たのである，ERCPによる膵胆管疾患へのアプ ローチから，それが困難な症例では EUSによ る治療アプローチへと変革しつつある。より安 全で患者にとって, より負担の少ない, より安 全な方法が出現すればよいと願っている。新し い機器の開発とそれに連結する治療法の展開に ついて, 月刊誌「胆と膵」でインタービューを 受けた記事があるので紹介しておきたい ${ }^{24}$.「新 しいものに勝るものはない」と信じている.

\section{7. 謝 辞}

初期においては指導と支援をいただいた小 林太刀夫教授, 林田健男教授, 城所仂教授, 㟝 田隆夫教授の諸先輩はじめ, 身近には相馬智教 授のご指導があって初めてこの研究は完成しま 
(18) 医機学 Vol.85, No. 5 (2015)

した．機器，処置具の開発には当時のオリンパ 又第三開発部の大内, 三井，宇津木氏らによる ところが大きかった．深甚の感謝を申し上げま す.

\section{文献}

1）宇治達郎, 胃粘膜撮影法とその応用に関する 研究, 東京医学雑誌, 1953, 61 : 135-142.

2) Hirschowitz,B.I.,Curtiss, LE,Peters, C. $\mathrm{W}$ and Pollard, H.M. Demonstration of a new gastroscope the "Fiberscope". Gastroenterology, 1958, 35 : p. 50-53.

3 ）石原國, 田中弘道, 野田定吉ほか, 十二指腸 カメラによる球部撮影の試み, Gastroenterol Endosc. 1962, 4 : p. 58-59.

4) McCune,W.S.,Shorb, P.E., Moscovits, H.,Endoscopic cannulationof the ampulla of Vater: a preliminary report. Ann Surg, 1968, $167:$ p. $752-755$.

5 ）大井至 Fiberduodenoscopeによる内視鏡的 膵管造影, 日消誌, 1969, 66 : p. 880-883.

6 ）高木國夫, 池田靖洋, 中川安房ほか, 十二指 腸ファイバースコピーの研究, 第 3 報 - 逆 行性膵管抒よび総胆管造影の 1 例 胃と腸, 1970, 5 : p. $103-111$.

7 ) 藤田力也, 相馬智, 城所仂 十二指腸の内視 鏡検査, Gastroenterol Endosc. 1970, 12 : p. $97-106$.

8 ) 進藤捷介, 菅家克彦, 柳沢文哉 十二指腸ファ イバースコープ, Gastroenterol Endosc. 1970, 12 : p. $70-78$.

9 ）小越和栄, 飛田祐吉, 原義雄, 十二指腸 の内視鏡観察および内視鏡的膵胆管造影 Endoscopic Observation of the Duodenum and Pancreato-Choledochography using Duodenal Fiberscope under direct Vision. Gastroentrol Endosc. 1970, 12 : p. 83-94.

10）藤田力也 今日の焦点一十二指腸ファイバー スコープによる新しい検査法一治療, 1971, $53:$ p. $1301-1313$.

11）小越和栄, 春日井達造 話題一EPCGかERCP
か, 胃と腸, $1975,10 ：$ p. 538-539.

12）相馬智, 小野美貴子, 藤田力也ほか, 内視鏡 的乳頭切開術および遺残胆道結石摘出の試み 一第1報一Gastroenterol Endosc. 1974, 16 : p. $446-452$.

13) Classen,M ,Demling L Endoskopische Sphincterotomie der Papilla Vateri und Steinextraktion aus dem Ductus Choledochus, DMW, 1974 : 99 : p. 496-497.

14) Kawai $K$, Akasaka $Y$, Hashimoto $Y$, Nakajima M.,Preliminary report on endoscopical papillotomy. 1973, 82 : p. 353-355.

15) Kawai K, Akasaka Y, Murakami K, et al, Endoscopic sphincterotomy of ampulla of Vater, Gastrointest Endosc, 1974, 20 : p. 148151.

16) 小野慶一, 経十二指腸括約筋切開術, 消化器 外科, $1982,5:$ p. $1366-1378$.

17）相馬智, 小野美貴子, 電気入久はなぜ切れる か一筆者らの考え方一, 臨床外科, 1977, 32:p. $1573-1576$.

18）永井規敬, 内視鏡的膵胆管カテーテル持続 留置法に関する研究, Gastroenterol Endosc. 1975, 17 : p. 684-699.

19) Wurbs D, Phlip J, Classen M, Experiences with the long standing nasobiliary tube in biliary diseases. Endoscopy, 1980, 12 : p. 219223.

20) Soehendra,N. Reynders-Fredrix V, Palliative Gallengang-Drainage.Dtsch Med Wschr. 1979, $104:$ p. $206-7$.

21) Fujita R, Hirata N, Fujita Y. Peroral Cholecystoscopy, Endoscopy, 1989, 21 : p. 378-380.

22）藤田力也, 池田靖洋編, 胆道疾患の非観血的 治療手技，1993，金原出版，東京.

23) OMED bulletin No.7, edt. Niwa H, Fujita R. Secretary General Report, 6-8, Tokyo, 2013.

24）福嶋敬宣，その《道》の究め方一消化器病に 挑み続ける先駆者たち一第八回（藤田力也） 胆と膵, $2008,29:$ p. $763-770$. 